\title{
ANALYTICAL ASSESSMENT OF MAIZE KERNELS FOR Fe, Zn, AND $\beta$-CAROTENE DENSE CULTIVARS WITH LOW PHYTATE CONTENTS
}

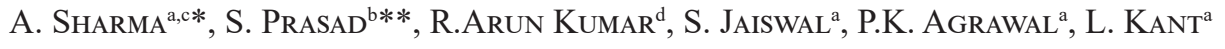 \\ and J.C. BHATT ${ }^{\mathrm{a}}$

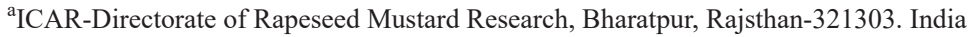 \\ ${ }^{\mathrm{b}}$ School of Biological and Chemical Sciences, Faculty of Science, Technology and Environment, The University of \\ the South Pacific, Suva. Fiji \\ ${ }^{\mathrm{c}}$ Crop Improvement Division, Indian Council of Agricultural Research (ICAR), Vivekananda Parvatiya Krishi \\ Anusandhan Sansthan (VPKAS), Almora 263601, Uttarakhand. India \\ ${ }^{\mathrm{d}}$ ICAR-Sugarcane Breeding Institute, Coimbatore-641007, Tamil Nadu. India
}

(Received: 3 May 2019; accepted: 17 September 2019)

The present paper reports that significant genetic variability was evident in $\mathrm{Fe}, \mathrm{Zn}, \beta$-carotene, and phytic acid (phytate, PA) contents in a set of 39 diverse maize genotypes collected from maize breeding programme of hill agriculture, India. The Fe, $\mathrm{Zn}, \beta$-carotene, and PA concentrations were found to be in the range $19.31-50.64 \mathrm{mg} \mathrm{kg}^{-1}$, 12.60-37.18 $\mathrm{mg} \mathrm{kg}^{-1}, 0.17-8.27 \mu \mathrm{g} \mathrm{g}^{-1}$, and 6.59-7.13 $\mathrm{g} \mathrm{kg}^{-1}$, respectively. The genotypes V335, V420, V393, V416, V414, V372, and V351 were identified to have higher concentration of $\beta$-carotene, Fe, and Zn but lower amount of PA. Possible availability of the minerals Fe and $\mathrm{Zn}$ was determined using molar ratio between PA as inhibitor and $\beta$-carotene as promoter for their absorption. The micronutrient molar ratio showed that Fe and $\mathrm{Zn}$ traits could be dependent of each other. Low $\mathrm{R}^{2}$ value revealed relation between $\beta$-carotene and kernel colour. The selected genotypes could be considered as potential sources of favourable genes for further breeding programs to develop micronutrient enriched maize cultivars.

Keywords: maize, micronutrients, $\beta$-carotene, phytic acid, breeding

Humans require at least 49 nutrients to meet their caloric intake so they use mainly cereal crops as staple food (CHASsY, 2010). Micronutrients are essential for growth and development in plants, animals, as well as in humans (Gomez-GALERA et al., 2010). These bioavailable micronutrients such as iron $(\mathrm{Fe})$, zinc $(\mathrm{Zn})$, and vitamin A perform a variety of functions in plant cells. It has been estimated that over three billion people are currently malnourished because of lack of minerals, especially Fe and Zn, in their diet (GoudiA \& HASH, 2015). Maize kernel coloured by carotenoid compounds are generally converted to vitamin A in humans as well as in animals. Carotenoids ( $\beta$-carotene, $\beta$-cryptoxanthin, and $\alpha$-carotene) are natural pigments that occur widely in plants and serve as a major source of vitamin $\mathrm{A}$ and antioxidants that play important roles in human nutrition. It has been reported that white maize has low levels of total carotenoids and does not have provitamin A carotenoids (pVAC), while common yellow maize has high amount of total carotenoids (TALEON et al., 2017). The cereal grains such as maize have a high amount of mineral inhibitors, such as PA (phytic acid) and phenolic compounds, including condensed tannins (GABAZA et al., 2018). It chelates with

\footnotetext{
* To whom correspondence should be addressed.

** Phone: +91 7579269471, +91 5962230060 (A. Sharma); +679 3232416 (S. Prasad)

E-mails: sharmaanubhuti98@gmail.com (A. Sharma); prasad_su@usp.ac.fj (S. Prasad)
} 
essential minerals such as $\mathrm{Fe}$ and $\mathrm{Zn}$ as it passes through the digestive system of humans and other mono-gastric animals, which leads to increasing Fe and $\mathrm{Zn}$ deficiencies in communities that subsist mainly on maize as their daily food. Thus, the present work addresses the genetic variability in micronutrient traits of maize kernels, involving selected inbred lines, to provide relevant information for development of maize cultivars with improved contents of $\mathrm{Fe}, \mathrm{Zn}$, and $\beta$-carotene coupled with low PA.

\section{Materials and methods}

Maize genotypes were collected from the maize breeding programme of VPKAS, Almora, Uttarakhand, India. The maize kernel samples were classified on the basis of their colour variation into yellow, dark yellow, orange, and dark orange as shown in Figure 1. The seeds of 39 maize genotypes ( $50 \mathrm{~g}$ each) were taken from germplasm maintained by the maize breeding programme in a similar environment at VPKAS. The sieved fine flour of each genotype was packed in water-proof butter paper bags and kept at $4{ }^{\circ} \mathrm{C}$ till the extraction of carotenoids and micronutrients $\mathrm{Fe}$ and $\mathrm{Zn}$.

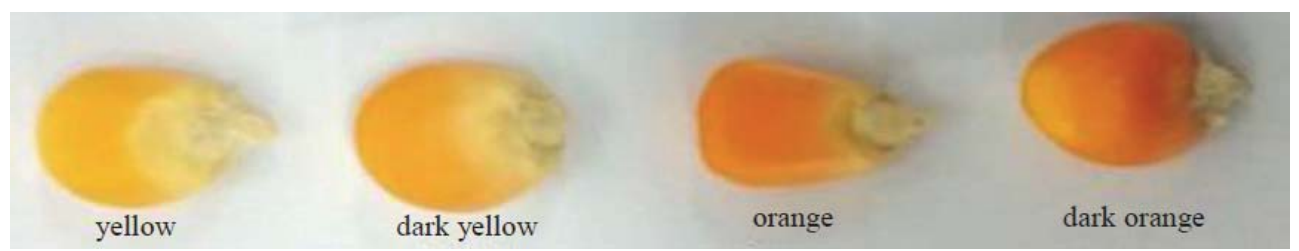

Fig. 1. Classification of maize kernel based on colour variation as yellow, dark yellow, orange, and dark orange

The Kjeldahl method was used for protein estimation in maize kernel (NKONGE \& BALANCE, 1982). The $\beta$-carotene was determined following spectrophotometric AACC method (AACC, 1995). The individual fine flour samples of each genotype in triplicate were digested with concentrated $\mathrm{HNO}_{3}$ acid. The concentrations of $\mathrm{Fe}$ and $\mathrm{Zn}$ in maize kernel samples were determined using atomic absorption spectrophotometer (AAS-Analytic Jena, Germany) following the protocol reported by ZARCINAS and co-workers (1987) with some modifications.

The concentrations of PA phosphorus (Pphy) and inorganic phosphorous (Pi) in maize kernel were determined using the colourimetric method of LoRENZ and co-workers (2008). The moles of PA and minerals were determined by dividing the molecular weight of PA, $\beta$-carotene, and atomic weights of $\mathrm{Fe}$ and $\mathrm{Zn}$ micronutrients.

The significance of the results was verified with one-way analysis of variance (ANOVA) followed by Duncan's multiple range test $(\mathrm{P}<0.05)$. The principal component analysis $(\mathrm{PCA})$ and two way agglomerative hierarchical clustering (AHC) was used to display the correlations between the various biochemical parameters and 39 maize genotypes. The statistical analyses were performed using the SAS JMP version 9.0. 


\section{Result and discussion}

The analysis of 39 genotypes of maize revealed wide range of $\beta$-carotene contents as shown in Table 1. The higher $\beta$-carotene contents $\left(>6-8 \mu \mathrm{g} \mathrm{g}^{-1}\right)$ were found in grains of V391, V419, V420, V393, V335, V416, and V414 genotypes. It has been reported that an increased $\beta$-carotene content enables better mineral nutrient absorption by forming a complex with micronutrients ( $\mathrm{Fe}$ and $\mathrm{Zn}$ ) that keeps it soluble in the intestinal lumen and prevents the mineral assimilation of PA (LÖNNERDAL, 2003). Therefore, it is important to note that higher $\beta$-carotene concentration could have positive effect on absorption of mineral nutrients, possibly by decreasing deleterious effect of PA (DRAGIČEVIĆ et al., 2013). This proposition is further supported by the lower Pphy/ $\beta$-carotene ratio $(<850)$ in case of V391, V420, V393, V335, V416, V419, and V414 lines as shown in Table 2. In the breeding program for selection of high carotene maize lines, SAFAwO and co-workers (2010) have also determined high variation in $\beta$-carotene contents of maize grains.

Table 1. Protein, $\beta$-carotene, Fe, Zn, phytic acid phosphorus (Pphy), inorganic phosphorus (Pi) contents and kernel colour in dry maize genotypes (y- yellow, dy- dark yellow, o- orange, do- dark orange)

\begin{tabular}{|c|c|c|c|c|c|c|c|}
\hline Genotypes & Colour & $\begin{array}{c}\text { Protein } \\
(\%)\end{array}$ & $\begin{array}{c}\beta \text {-carotene } \\
\left(\mu \mathrm{g} \mathrm{g}^{-1}\right)\end{array}$ & $\begin{array}{c}\mathrm{Fe} \\
\left(\mathrm{mg} \mathrm{kg}^{-1}\right)\end{array}$ & $\begin{array}{c}\mathrm{Zn} \\
\left(\mathrm{mg} \mathrm{kg}^{-1}\right)\end{array}$ & $\begin{array}{c}\text { Pphy } \\
\left(\mathrm{mg} \mathrm{g}^{-1}\right)\end{array}$ & $\begin{array}{c}\mathrm{Pi} \\
\left(\mathrm{mg} \mathrm{g}^{-1}\right)\end{array}$ \\
\hline V341 & $\mathrm{y}$ & $8.11 \pm 0.00$ & $2.09 \pm 0.29$ & $35.92 \pm 2.40$ & $22.95 \pm 0.08$ & $6.74 \pm 0.001$ & $0.125 \pm 0.021$ \\
\hline V345 & $\mathrm{y}$ & $6.23 \pm 0.18$ & $3.17 \pm 0.48$ & $32.69 \pm 0.60$ & $24.55 \pm 1.77$ & $6.99 \pm 0.006$ & $0.161 \pm 0.003$ \\
\hline V346 & $\mathrm{y}$ & $7.95 \pm 0.05$ & $1.66 \pm 1.23$ & $30.30 \pm 0.79$ & $33.07 \pm 2.02$ & $6.72 \pm 0.008$ & $0.208 \pm 0.004$ \\
\hline V378 & $\mathrm{y}$ & $8.21 \pm 0.01$ & $0.17 \pm 0.03$ & $42.48 \pm 4.80$ & $25.01 \pm 0.07$ & $6.82 \pm 0.006$ & $0.156 \pm 0.010$ \\
\hline V382 & $\mathrm{y}$ & $8.94 \pm 0.05$ & $2.47 \pm 1.10$ & $40.70 \pm 2.18$ & $26.83 \pm 0.71$ & $6.72 \pm 0.018$ & $0.411 \pm 0.014$ \\
\hline V400 & $\mathrm{y}$ & $8.69 \pm 0.01$ & $0.43 \pm 0.13$ & $22.06 \pm 1.53$ & $14.78 \pm 1.20$ & $6.59 \pm 0.000$ & $0.148 \pm 0.009$ \\
\hline V421 & $\mathrm{y}$ & $7.76 \pm 0.04$ & $0.89 \pm 0.46$ & $32.32 \pm 2.01$ & $23.45 \pm 1.64$ & $6.62 \pm 0.012$ & $0.149 \pm 0.034$ \\
\hline V428 & $\mathrm{y}$ & $7.66 \pm 0.04$ & $0.71 \pm 0.62$ & $32.84 \pm 2.06$ & $12.60 \pm 1.52$ & $6.84 \pm 0.003$ & $0.258 \pm 0.003$ \\
\hline VQL1 & $\mathrm{y}$ & $7.53 \pm 0.02$ & $1.07 \pm 0.15$ & $29.21 \pm 1.92$ & $24.50 \pm 0.95$ & $6.89 \pm 0.005$ & $0.247 \pm 0.007$ \\
\hline VQL17 & $\mathrm{y}$ & $6.49 \pm 0.02$ & $1.21 \pm 0.41$ & $36.64 \pm 0.63$ & $20.17 \pm 1.25$ & $6.82 \pm 0.011$ & $0.313 \pm 0.001$ \\
\hline V420 & dy & $8.07 \pm 0.05$ & $7.41 \pm 1.62$ & $44.76 \pm 0.82$ & $23.21 \pm 0.25$ & $6.62 \pm 0.007$ & $0.233 \pm 0.003$ \\
\hline V335 & dy & $10.82 \pm 0.03$ & $7.70 \pm 0.33$ & $37.86 \pm 1.31$ & $18.14 \pm 0.50$ & $6.65 \pm 0.008$ & $0.134 \pm 0.002$ \\
\hline V336 & dy & $9.11 \pm 0.08$ & $2.22 \pm 0.34$ & $47.52 \pm 3.04$ & $21.70 \pm 0.24$ & $6.74 \pm 0.018$ & $0.355 \pm 0.020$ \\
\hline V338 & dy & $7.12 \pm 0.04$ & $2.07 \pm 0.32$ & $37.86 \pm 3.36$ & $20.61 \pm 0.43$ & $6.91 \pm 0.001$ & $0.245 \pm 0.003$ \\
\hline V351 & dy & $9.73 \pm 0.05$ & $4.68 \pm 1.82$ & $50.64 \pm 1.31$ & $24.45 \pm 1.54$ & $6.83 \pm 0.001$ & $0.102 \pm 0.005$ \\
\hline V392 & dy & $7.91 \pm 0.02$ & $2.73 \pm 0.47$ & $48.33 \pm 4.52$ & $24.02 \pm 0.37$ & $6.99 \pm 0.007$ & $0.218 \pm 0.020$ \\
\hline V393 & dy & $9.50 \pm 0.04$ & $7.17 \pm 0.21$ & $39.51 \pm 0.00$ & $20.19 \pm 0.82$ & $6.93 \pm 0.003$ & $0.387 \pm 0.027$ \\
\hline V402 & dy & $7.48 \pm 0.02$ & $0.31 \pm 0.28$ & $32.67 \pm 0.88$ & $19.18 \pm 2.56$ & $6.74 \pm 0.002$ & $0.184 \pm 0.005$ \\
\hline V403 & dy & $7.90 \pm 0.01$ & $3.29 \pm 0.61$ & $47.90 \pm 0.61$ & $26.34 \pm 0.41$ & $6.70 \pm 0.001$ & $0.208 \pm 0.001$ \\
\hline V411 & dy & $7.04 \pm 0.00$ & $1.28 \pm 0.21$ & $37.43 \pm 1.11$ & $20.89 \pm 0.77$ & $6.80 \pm 0.002$ & $0.122 \pm 0.010$ \\
\hline V413 & dy & $8.24 \pm 0.04$ & $0.53 \pm 0.26$ & $45.46 \pm 4.54$ & $14.45 \pm 1.94$ & $6.82 \pm 0.015$ & $0.166 \pm 0.011$ \\
\hline V25 & do & $9.23 \pm 0.04$ & $3.38 \pm 0.41$ & $35.51 \pm 3.62$ & $20.47 \pm 1.51$ & $7.07 \pm 0.013$ & $0.146 \pm 0.016$ \\
\hline V372 & do & $9.55 \pm 0.05$ & $4.85 \pm 1.77$ & $30.83 \pm 1.04$ & $37.18 \pm 2.09$ & $6.86 \pm 0.026$ & $0.130 \pm 0.003$ \\
\hline V373 & do & $8.14 \pm 0.05$ & $3.45 \pm 1.41$ & $32.18 \pm 0.84$ & $29.28 \pm 1.38$ & $6.78 \pm 0.018$ & $0.228 \pm 0.007$ \\
\hline V390 & do & $10.94 \pm 0.04$ & $2.09 \pm 0.20$ & $19.31 \pm 1.14$ & $14.21 \pm 1.68$ & $7.13 \pm 0.030$ & $0.324 \pm 0.004$ \\
\hline V391 & do & $9.18 \pm 0.02$ & $8.27 \pm 0.30$ & $31.49 \pm 1.49$ & $20.78 \pm 2.00$ & $6.91 \pm 0.007$ & $0.224 \pm 0.004$ \\
\hline
\end{tabular}




\begin{tabular}{lccccccc}
\hline Genotypes & Colour & $\begin{array}{c}\text { Protein } \\
(\%)\end{array}$ & $\begin{array}{c}\beta \text {-carotene } \\
\left(\mu \mathrm{g} \mathrm{g}^{-1}\right)\end{array}$ & $\begin{array}{c}\mathrm{Fe} \\
\left(\mathrm{mg} \mathrm{kg}^{-1}\right)\end{array}$ & $\begin{array}{c}\mathrm{Zn} \\
\left(\mathrm{mg} \mathrm{kg}^{-1}\right)\end{array}$ & $\begin{array}{c}\text { Pphy } \\
\left(\mathrm{mg} \mathrm{g}^{-1}\right)\end{array}$ & $\begin{array}{c}\text { Pi } \\
\left(\mathrm{mg} \mathrm{g}^{-1}\right)\end{array}$ \\
\hline V396 & do & $9.50 \pm 0.01$ & $4.81 \pm 1.33$ & $48.32 \pm 2.61$ & $19.98 \pm 0.33$ & $6.82 \pm 0.007$ & $0.262 \pm 0.008$ \\
V407 & do & $8.30 \pm 0.01$ & $1.87 \pm 0.58$ & $34.15 \pm 0.17$ & $22.73 \pm 3.36$ & $7.04 \pm 0.003$ & $0.204 \pm 0.008$ \\
V409 & do & $9.41 \pm 0.04$ & $0.82 \pm 0.26$ & $34.12 \pm 1.40$ & $22.20 \pm 0.44$ & $6.91 \pm 0.007$ & $0.309 \pm 0.008$ \\
V414 & do & $10.64 \pm 0.04$ & $6.54 \pm 0.59$ & $47.26 \pm 2.94$ & $21.83 \pm 0.76$ & $6.66 \pm 0.011$ & $0.174 \pm 0.004$ \\
V416 & do & $8.66 \pm 0.04$ & $6.48 \pm 0.95$ & $41.13 \pm 0.44$ & $24.21 \pm 0.05$ & $6.79 \pm 0.005$ & $0.145 \pm 0.003$ \\
VQL2 & do & $7.86 \pm 0.00$ & $1.49 \pm 0.25$ & $32.09 \pm 4.45$ & $24.82 \pm 2.48$ & $6.72 \pm 0.015$ & $0.202 \pm 0.027$ \\
V410 & o & $9.19 \pm 0.09$ & $0.29 \pm 0.20$ & $36.01 \pm 1.09$ & $22.86 \pm 0.90$ & $6.86 \pm 0.005$ & $0.280 \pm 0.002$ \\
V417 & o & $6.84 \pm 0.05$ & $3.80 \pm 0.59$ & $36.02 \pm 3.92$ & $26.28 \pm 2.17$ & $6.71 \pm 0.002$ & $0.123 \pm 0.000$ \\
V419 & o & $8.07 \pm 0.00$ & $7.59 \pm 0.08$ & $42.54 \pm 1.20$ & $20.05 \pm 1.88$ & $6.93 \pm 0.003$ & $0.384 \pm 0.066$ \\
V406 & o & $8.61 \pm 0.05$ & $0.25 \pm 0.17$ & $28.34 \pm 1.12$ & $15.29 \pm 1.44$ & $6.79 \pm 0.009$ & $0.193 \pm 0.004$ \\
VQL26 & o & $8.66 \pm 0.04$ & $2.65 \pm 0.08$ & $23.46 \pm 0.57$ & $22.67 \pm 1.45$ & $6.78 \pm 0.009$ & $0.211 \pm 0.001$ \\
CM145 & o & $9.09 \pm 0.00$ & $0.55 \pm 0.15$ & $30.60 \pm 2.38$ & $23.32 \pm 0.77$ & $6.74 \pm 0.025$ & $0.139 \pm 0.004$ \\
CM153 & o & $10.02 \pm 0.02$ & $0.53 \pm 0.28$ & $42.93 \pm 1.97$ & $20.36 \pm 1.03$ & $6.91 \pm 0.009$ & $0.191 \pm 0.005$ \\
Popula- & - & $8.52 \pm 0.05$ & $2.90 \pm 0.31$ & $36.70 \pm 0.61$ & $22.30 \pm 0.32$ & $6.82 \pm 0.54$ & $1.92 \pm 0.05$ \\
tions mean & & & & & & &
\end{tabular}

The relationship between maize kernel colour and $\beta$-carotene, i.e. pro-vitamin $\mathrm{A}$, is presented in Figure 2, where scale $0.5-4.5$ on $\mathrm{X}$-axis represents the kernel colour. The $\beta$-carotene contents in yellow or dark yellow colour kernels were found to vary from the minimum of $0.17 \mu \mathrm{g} \mathrm{g}^{-1}$ (V378) to the maximum of $7.70 \mu \mathrm{g} \mathrm{g}^{-1}$ (V335) dry weight. However, in the case of orange or dark orange coloured kernels, $\beta$-carotene contents varied from the minimum of $0.25 \mu \mathrm{g} \mathrm{g}^{-1}$ (V406) to the maximum of $8.27 \mu \mathrm{g} \mathrm{g}^{-1}$ (V391) dry weight. HARJES and co-workers (2008) reported high variability of carotenoids from $5.5 \mu \mathrm{g} \mathrm{g}^{-1}$ to $66.0 \mu \mathrm{g} \mathrm{g}^{-1}$ with mean value of yellow lines as $23 \mu \mathrm{g} \mathrm{g}^{-1}$. BERARDO and co-workers (2009) analysed 1245 samples of maize and reported carotenoids from 1.09 to $61.10 \mu \mathrm{g} \mathrm{g}^{-1}$ dry weight. As per the $\mathrm{FAO} / \mathrm{WHO}$ recommendation, an adult male and female (between age of 25 and 50 years) require 1000 and $800 \mu \mathrm{g}$ vitamin $\mathrm{A}$, respectively, in their daily diet (FAO/WHO, 2001).

The genetic variability in phytate $\mathrm{P}$ (Pphy) content was also observed, with values ranging from 6.59 (V400) to $7.13 \mathrm{mg} \mathrm{g}^{-1}$ (V390) as presented in Table 1. High levels of inorganic $\mathrm{P}(\mathrm{Pi})$ are regarded as desirable from a nutritional standpoint (DRINIC et al., 2009). The Pi concentration was in the range from 0.102 (V351) to $0.411 \mathrm{mg} \mathrm{g}^{-1}$ (V382). The data presented in Table 1 clearly show that in comparison to Pphy, a higher genetic variation was observed for Pi contents in this study. These values of Pphy and Pi are within the range of previously reported values for different genotypes of maize (LORENZ et al., 2008).

The present study showed the significant differences for kernel Fe and $\mathrm{Zn}$ concentrations among the genotypes (Table 1). The range for the kernel Fe and $\mathrm{Zn}$ concentrations varied from 19.31-50.64 $\mathrm{mg} \mathrm{kg}^{-1}$ and 12.60-37.18 $\mathrm{mg} \mathrm{kg}^{-1}$, respectively, among the inbred lines. The genotype V351 showed the highest kernel Fe concentration as $50.64 \mathrm{mg} \mathrm{kg}^{-1}$, while V390 showed the lowest as $19.31 \mathrm{mg} \mathrm{kg}^{-1}$. Moreover, genotypes V378, V382, V420, V336, V392, V393, V403, V413, V396, V414, V416, V419, and CM153 with kernel Fe contents of more than $40 \mathrm{mg} \mathrm{kg}^{-1}$ were found highly promising, thus could be considered as a potential source of $\mathrm{P}$ and $\mathrm{Fe}$ in further breeding programs for improved mineral elements bioavailability. The results were almost similar with that reported for average kernel Fe concentration as $68.1 \mathrm{mg}$ $\mathrm{kg}^{-1}$ among maize lines (CHEN et al., 2007). The range of everyday recommended Fe ingestion 
is $8 \mathrm{mg} \mathrm{d}^{-1}$ for males and $18 \mathrm{mg} \mathrm{d}^{-1}$ for females based on age and body weight (NIH, 2018). V372 had the highest kernel $\mathrm{Zn}$ concentration as $37.18 \mathrm{mg} \mathrm{kg}^{-1}$, whereas V428 showed the lowest $\mathrm{Zn}$ concentration as $12.60 \mathrm{mg} \mathrm{kg}^{-1}$. In addition, V346, V378, V372, V373, V382, V403, and V417 genotypes showed higher Zn concentration, i.e. more than $25 \mathrm{mg} \mathrm{kg}^{-1}$ (Table 1). Similar variations in the concentrations of kernel $\mathrm{Fe}$ and $\mathrm{Zn}$ as $9.6-63.2 \mathrm{mg} \mathrm{kg}^{-1}$ and 12.9-57.6 $\mathrm{mg} \mathrm{kg}^{-1}$, respectively, have been reported by BANZIGER and LoNG (2000). IMRAN and Reнim (2017) also mentioned that $\mathrm{Zn}$ concentration ranged from 22.3 to $41.9 \mathrm{mg} \mathrm{kg}^{-1}$ in maize grain, and zinc fertilization increased bioavailability to 2.04-2.40.

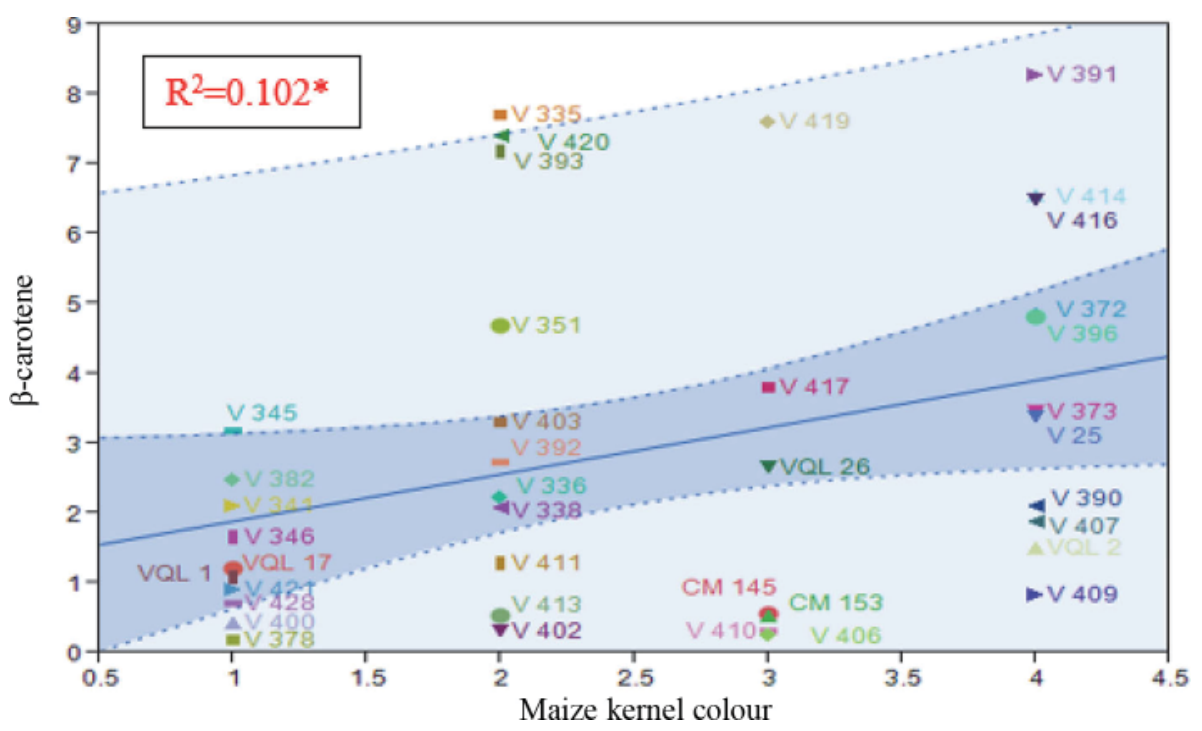

Fig. 2. Relationship between kernel colour and $\beta$-carotene (pro-vitamin A) content in the maize kernel. Scale 0.5-4.5 represents kernel colour class where 1: yellow; 2: dark yellow; 3: orange; 4: dark orange (For colours see the Electronic Supplementary Material on the article's website)

The calculated molar ratios of Pphy/Pi, Pphy/ $/$-carotene, Pphy/Fe, and Pphy/Zn (Norhaizan \& FAIZADatul, 2009) are presented in Table 2. The Pphy/Zn and Pphy/Fe molar ratios ranged from 18-54 and 11-31, respectively. Similarly, V419, V420, V393, V382, V335, V416, V414, V373, V417, V372, and V346 have favourable ratio of Pphy and Fe $(<20)$ indicating higher potential for Fe bioavailability. The genotypes V372, V346, V373, V382, V417, and V403 showed lower values $(<25)$ for the Pphy/Zn molar ratio as 18, 20, 23, 25, 25, and 25, respectively. Regarding Pphy/Fe molar ratio, the best results (lowest) were found in genotypes V351 (11.44), V414 (11.95), and V396 (11.98). Thus, this study indicated that V420, V414, V403, and V382 showed higher potential for Fe and Zn bioavailability, which are compatible with those examined in maize consumed in Southern Ethiopia (ABEBE et al., 2007). Similarly, $\beta$-carotene absorption efficiency also depends on $\mathrm{Zn}$ concentration in human plasma and in consumed food (NoH \& KoO, 2003). Uncommonly high contents of Zn and $\beta$-carotene were noticed in grains of V345, V351, V372, V373, and V416, which are also in the group of genotypes with Pphy $>6.78 \mathrm{mg} \mathrm{g}^{-1}$ (Table 1), making them desirable in breeding programs for increased $\mathrm{Zn}$ availability. 
Table 2. Molar ratios between $\mathrm{PA} / \mathrm{Pi}, \mathrm{PA} / \beta$-carotene, $\mathrm{PA} / \mathrm{Fe}$, and $\mathrm{PA} / \mathrm{Zn}$ present in studied maize kernels

\begin{tabular}{|c|c|c|c|c|}
\hline Genotypes & Phytate/Pi & Phytate $/ \beta$-carotene & Phytate/Fe & Phytate/Zn \\
\hline V341 & 8 & 2620 & 16 & 29 \\
\hline V345 & 6 & 1790 & 18 & 28 \\
\hline V346 & 5 & 3290 & 19 & 20 \\
\hline V378 & 6 & 32600 & 14 & 27 \\
\hline V382 & 2 & 2210 & 14 & 25 \\
\hline V400 & 6 & 12450 & 25 & 44 \\
\hline V421 & 6 & 6040 & 17 & 28 \\
\hline V428 & 4 & 7830 & 18 & 54 \\
\hline VQL1 & 4 & 5230 & 20 & 28 \\
\hline VQL17 & 3 & 4580 & 16 & 33 \\
\hline V420 & 4 & 725 & 13 & 28 \\
\hline V335 & 7 & 702 & 15 & 36 \\
\hline V336 & 3 & 2470 & 12 & 31 \\
\hline V338 & 4 & 2710 & 15 & 33 \\
\hline V351 & 10 & 1190 & 11 & 28 \\
\hline V392 & 5 & 2080 & 12 & 29 \\
\hline V393 & 3 & 785 & 15 & 34 \\
\hline V402 & 5 & 1770 & 18 & 35 \\
\hline V403 & 5 & 1650 & 12 & 25 \\
\hline V411 & 8 & 4320 & 15 & 32 \\
\hline V413 & 6 & 10450 & 13 & 46 \\
\hline $\mathrm{V} 25$ & 7 & 1700 & 17 & 34 \\
\hline V372 & 8 & 1150 & 19 & 18 \\
\hline V373 & 4 & 1600 & 18 & 23 \\
\hline V390 & 3 & 2770 & 31 & 49 \\
\hline V391 & 4 & 679 & 19 & 33 \\
\hline V396 & 4 & 1150 & 12 & 34 \\
\hline V407 & 5 & 3060 & 17 & 30 \\
\hline V409 & 3 & 6840 & 17 & 31 \\
\hline V414 & 6 & 827 & 12 & 30 \\
\hline V416 & 7 & 851 & 14 & 28 \\
\hline VQL2 & 5 & 3660 & 18 & 27 \\
\hline V410 & 4 & 19220 & 16 & 30 \\
\hline V417 & 8 & 1430 & 16 & 25 \\
\hline V419 & 3 & 742 & 14 & 34 \\
\hline V406 & 5 & 22100 & 20 & 44 \\
\hline VQL6 & 5 & 2080 & 25 & 29 \\
\hline CM45 & 7 & 9960 & 19 & 28 \\
\hline CM153 & 5 & 10590 & 14 & 33 \\
\hline
\end{tabular}


Significant and negative correlation between Pphy and Fe contents, while positive correlation between $\mathrm{Zn}$ and Fe concentrations were obtained in maize grains, which shows that maize kernel with low Pphy could be a good source of $\mathrm{Zn}$ and Fe. High concentrations of $\mathrm{Fe}$ and $\mathrm{Zn}$ were found in V393, V419, V416, making them relatively high nutritional quality maizes. In legumes, phytates are associated with protein bodies and also reported that their levels increase with increasing protein content (Sparvoli \& CominelLi, 2015). Variability in total protein content was observed, with values ranging from $6.23 \%$ in V345 to $10.94 \%$ in V390 (Table 1). However, V391, V335, V393, V420, V414, V372, and V396 showed higher amounts of protein contents of 9.18, 10.82, 9.50, 8.07, 10.64, and 9.50\%, respectively, and are good sources of protein.

The presence of such genetic variation for the micronutrient traits, coupled with high $\beta$-carotene and low PA contents is highly encouraging, as this provides a possibility to breed high $\beta$-carotene yielding maize genotypes having low PA. On the basis of above discussion,V335, V420, V393, V416, V414, V391, V419, and V351 genotypes can be selected as the most promising genotypes with high amounts of $\beta$-carotene, Fe, $\mathrm{Zn}$, and protein, and low amount of PA.

As shown in Figure 2, significant $(\mathrm{P}<0.05)$ positive correlation $\left(\mathrm{R}^{2}=0.102^{*}\right)$ between maize kernel colour and $\beta$-carotene (pro-vitamin A) contents was observed showing regression equation as: Pro-vitamin $\mathrm{A}=1.221+0.673 \times$ kernel colour. The low $\mathrm{R}^{2}$ value from regression analysis is mainly due to sizable variation of $\beta$-carotene contents in each classes of maize kernel colour. HARJES and co-workers (2008) also observed low $\mathrm{R}^{2}$ value between carotenoid lycopene and kernel colour among a set of 228 diverse maize inbred lines. Similar results have been reported in the literature in selected tropical maize genotypes for total carotenoid content and kernel colour (SIVARANJANI et al., 2013).

The loading and scatter plots of maize genotypes studied using PCA are shown in Figures $3 \mathrm{~A}$ and $3 \mathrm{~B}$, respectively. The first principal component $(\mathrm{PC} 1)$ had the highest eigenvalue of 1.53 and accounted for $30.6 \%$ variability in the data set, while second principal component (PC2) had eigenvalue of 1.24 and accounted for $24.7 \%$ variability. All parameters except PA occupied the right side in the biplot in Figure 3A. Zn, Fe, and $\beta$-carotene (Pro-Vit A) are situated in the right upper side of the biplot with high positive loading for both PC1 and PC2, while protein can be observed with slightly lesser positive loadings on the right lower side of the biplot. The PCA clearly suggests that protein and $\beta$-carotene show significant positive correlation. However, negative correlation can be observed between protein and PA. Similarly, it is also observed that most promising genotypes with high amounts of $\beta$-carotene, $\mathrm{Fe}, \mathrm{Zn}$, and protein and low amount of PA occupies the right side of the scatter plot of maize genotypes as shown in Figure 3B. 

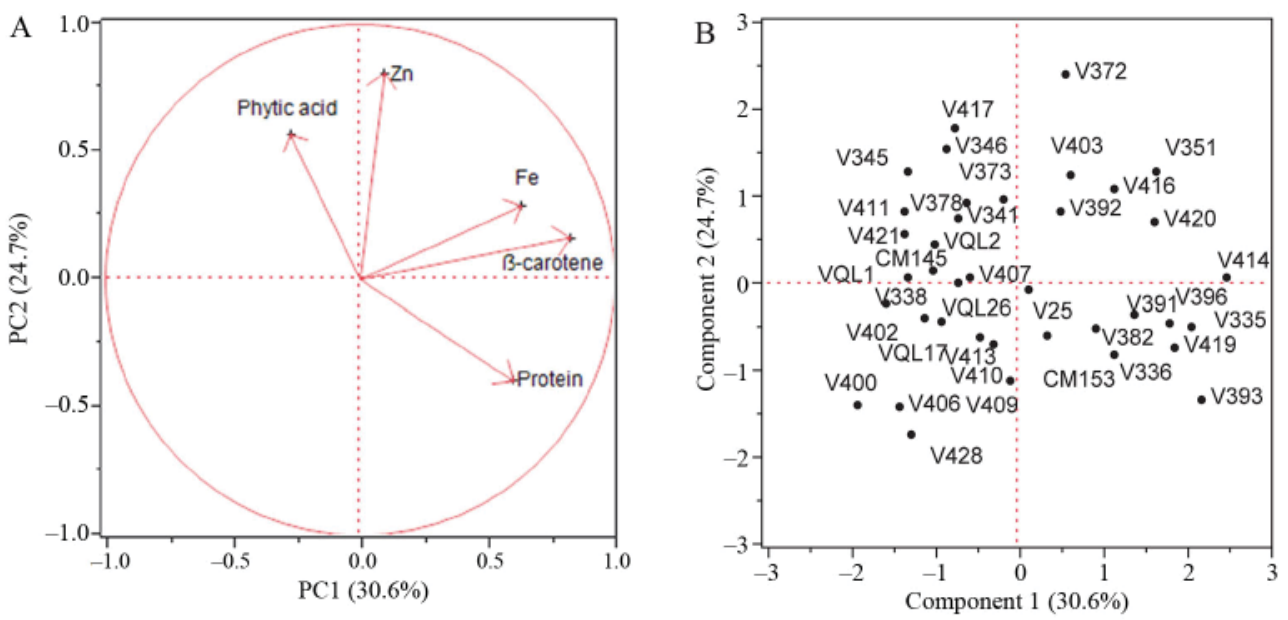

Fig. 3. A: Principal component analysis loading plot of maize genotypes and B: Principal component analysis scatter plot of maize genotypes

\section{Conclusions}

The study confirmed the significant genetic variability in maize kernels with respect to $\mathrm{Fe}$, $\mathrm{Zn}, \beta$-carotene, PA, and protein. Among the studied maize kernels V335, V420, V393, V416, V414, V391, and V419 genotypes were found with high amounts of $\beta$-carotene, Fe, Zn, and protein, and low amount of PA. Further, substantial genetic variability coupled with high heritability and weak association of $\mathrm{Fe}$ and $\mathrm{Zn}$ contents with $\beta$-carotene and PA contents suggest that it is possible to breed $\mathrm{Fe}, \mathrm{Zn}$, and $\beta$-carotene-dense cultivars with low PA contents.

The authors are grateful to the Indian Council of Agricultural Research, Government of India for financial support to carry out this work at VPKAS, Almora, Uttarakhand. S. Prasad is grateful to the University of the South Pacific for support.

\section{References}

AACC (1995): Approved methods of the AACC, $11^{\text {th }}$ ed. American Association of Cereal Chemists, The Association. St. Paul, MN, USA. Method 14-50.

Abebe, Y., Bogale, A., Michael H.K., Stoecker, B.J., Bailey, K. \& Gibson R.S. (2007): Phytate, zinc, iron and calcium content of selected raw and prepared foods consumed in rural Sidama, Southern Ethiopia, and implications for bioavailability. J. Food Compos. Anal., 20, 161-168.

BANZIGER, M. \& LONG, J. (2000): The potential for increasing the iron and zinc density of maize through plantbreeding. Food Nutr. Bull., 21, 397-400.

Berardo, N., Mazzinelli, G., Valoti, P., Lagana, P. \& Redaelli, R. (2009): Characterization of maize germplasm for the chemical composition of the grain. J. Agr. Food Chem., 57, 2378-2384.

Chen, F., Chun, L., Song, J. \& Mi, G. (2007): Heterosis and genetic analysis of iron concentration in grains and leaves of maize. Plant Breeding, 126, 107-109.

CHassy, B.M. (2010): Food safety risks and consumer health. New Biotechnol., 27, 534-544.

Dragičević, V., Mladenović-Drinić, S., Stojiljković, M., Filipović, M., Dumanović, Z. \& Kovačević, D. (2013): Variability of factors that affect availability of iron, manganese and zinc in maize lines. Genetika, 45, 907-920. 
Drinic, S.M., Ristic, D., Sredojevic S., Dragicevic, V., Micic, D.I., \& Delic, N. (2009): Genetic variation of phytate and inorganic phosphorus in maize population. Genetika, 41, 107-115.

FAO/WHO (1998): Preliminary report on recommended nutrient intakes. Joint FAO/WHO expert consultation on human vitamin and mineral requirements., FAO, Bangkok, Thailand, 21-30 September 1998. FAO/WHO, Geneva, Switzerland. 17 pages.

FAO/WHO (2001): Human vitamin and mineral requirements. Report of a joint FAO/WHO expert consultation, Bangkok, Thailand. FAO/WHO, Geneva, Switzerland. 303 pages.

Gabaza, M., Shumoy H., Muchumeti, M., Vandamme, P. \& Raes, K. (2018): Iron and zinc bioaccessibility of fermented maize, sorghum and millets from five locations in Zimbabwe. Food Res. Int., 103, 361-370.

Gomez-Galera, S., Rojas, E., Sudhakar, D., Zhu, C., Pelacho, A.M., .... \& Christou, P. (2010): Critical evaluation of strategies for mineral fortification of staple food crops. Transgenic Res., 19, 165-180.

Goudia, B.D. \& HASH, C.T. (2015): Breeding for high grain Fe and Zn levels in cereals. IJIAS., 12, $342-354$.

Harjes, C.E., Rocheford, T.R., Bai, L., Brutnell, T., Kandianis, C.B., ... \& Buckler, E.S. (2008): Natural genetic variation in lycopene epsilon cyclise tapped for maize biofortification. Science, 319, 330-333.

ImRAN, M. \& ReHIM, A. (2017): Zinc fertilization approaches for agronomic biofortification and estimated human bioavailability of zinc in maize grain. Arch. Agron. Soil Sci., 63, 106-116.

LÖNNERDAL, B. (2003): Genetically modified plants for improved trace element nutrition. J. Nutr., 133, 1490S-1493S.

LorenZ, A.J., ScotT, M.P. \& LAMKeY, K.R. (2008): Genetic variation and breeding potential of phytate and inorganic phosphorus in a maize population. Crop Sci., 48, 79-84.

NIH (2018): Iron: Health professional fact sheet. US Dept. Health Human Serv., Washington, DC. https://ods.od.nih. gov/factsheets/Iron-Health Professional/\#h2 (last accessed 2 Feb 2018).

Nkonge, C. \& Balance, M. (1982): A sensitive colourimetric procedure for nitrogen determination in MicroKjeldahl digest. J. Agr. Food Chem., 30, 416-420.

NoH, S.K. \& Koo, S.I. (2003): Low zinc intake decreases the lymphatic output of retinol in rats infused intraduodenally with beta-carotene. J. Nutr. Biochem., 14, 147-153.

Norhaizan, M.E. \& Faizadatul, A.W. (2009): Determination of phytate, iron, zinc, calcium contents and their molar ratios in commonly consumed raw and prepared food in Malaysia. Malays. J. Nutr. 15, $213-222$.

Safawo, T., Senthil, N., Raveendran, M., Vellaikumar, S.E., Ganesan, K.N., ... \& Gowri, V. (2010): Exploitation of natural variability in maize for $\beta$-carotene content using HPLC and gene specific markers. Electron. J. Plant Breed., 1, 548-555.

Sivaranjani, R., Prasanna, B.M., Hossain, F. \& Santha, I.M. (2013): Genetic variability for total carotenoid concentration in selected tropical maize (Zea mays) inbred lines. Indian J. Agr. Sci., 83, 431-436.

Sparvoli, F. \& Cominelli, E. (2015): Seed biofortification and phytic acid reduction: A conflict of interest for the plant. Plants, 4, 728-755.

Taleon, V., Mugode, L., Cabrera-Soto, L. \& Palacios-Rojas, N. (2017): Carotenoid retention in biofortified maize using different post-harvest storage and packaging methods. Food Chem., 232, 60-66.

Zarcinas, B.A., Cartwright, B. \& Spouncer, L.R. (1987): Nitric acid digestion and multi element analysis of plant material by inductively coupled plasma spectrometry. Commun. Soil. Sci. Plan., 18, 131-146. 